\title{
GISを用いた山地地形から三次元すべり危険斜面を 抽出する方法の開発と適用
}

\author{
周 国 云 ${ }^{*}$ ・江 崎哲 郎 ${ }^{* *}$ ・謝謨 文 ${ }^{* * *}$ ・佐々木靖人 ${ }^{* * * *}$
}

\section{要 旨}

本研究では, 三次元斜面安定解析に必要な膨大な空間情報(地形, 地質, 傾斜角度, 地下水位, 弱層分布等)をGISで処理し, これらのデ ジタル情報を高度に利用する斜面安定解析コードを開発し，広域での三次元危険斜面の抽出方法を提案する。まず，数值地形(DEM)から 地域の同じ方向とみなせる単位斜面(Slope unit)を抽出する。次に，単位斜面に対して，棈球体と仮定した三次元すべり体を地盤と交差 させ，その交差面を三次元すべり面とし，その棈球体の寸法や形状をモンテカルロ法により乱数として発生し，さまざまな潜在的なすべ り面を作り出す．この仮想すべり面で囲まれたそれぞれのすべり体に対して, 三次元安定計算を行い, 最すすべり安全率の小さいすべり 体を検出する。この解析プロセスをすべての単位斜面に適用することによって, 広域における危険なすべり体の形状, 位置を特定するこ とができる.

Key words：地すべり landslide, 3 次元斜面崩壊 3D slope failure, 地理情報システム GIS， モンテカルロ法 Monte Carlo simulation

\section{1. は じめ に}

山地地形の多いわが国では土砂災害が多数発生し, 安全 の確保や経済的損失が大きな社会問題となっている. 毎年 平均 500 件余の崖崩れが発生し, 全国で 11 万以上の急傾斜 地崩壊危険箇所がある.

従来の地盤防災分野では, 評価が必要な斜面が予め指定 され, その安定評価がされてきた。しいしながら, 広域で の危険斜面の抽出, すなわち, 自然の複雑な山地地形の中 で, ぞの場所で, どのような規模と形態で不安定となるか についての視点が土砂災害の防止対策の実務に対しては極 めて重要であると考える。そのためには，さまざまな空間 情報の定量把握(地質, 地形, 地下水位, 弱層分布等)が必 要となるが，このような影響要素全般にわたる空間情報を ベースにした斜面崩壊予測システムの研究は立遅れている のが現状である.

*西日本工業大学 Nishinippon Institute of Technology

**九州大学環境システム科学研究センター Institute of Environmental Systems, Kyushu University(会員)

***九州大学環境システム科学研究センター Institute of Environmental Systems, Kyushu University

****(独) 土木研究所 Publics Works Research Institute (会員)
広域での不安定斜面を抽出する方法には大きく見れば定 性的および定量的な評価手法の 2 種類がある. 定性的な評 価は，過去に斜面不安定となった場所の地形，地質，地盤 の力学特性等との類似性から評価対象斜面の安定性を推定 する方法であり，概略的な斜面安定性評価手法である，定 量的な評価手法では, 力学モデルを使用しない数学・統計 的手法 (多变量解析, 数量化理論, 遺伝的アルゴリズム等) と力学モデルを取り入れる手法, すなわち, 確定モデル手 法(Deterministic model：無限斜面モデル等)がある。数 学・統計的手法による研究は, 代表的なものとして $\mathrm{CARRARA}^{1) \sim 3)}$, $\mathrm{HASEN}^{4) \sim 6)}$, Van $\mathrm{WESTEN}^{7,8)}$ および 大林 ${ }^{9,10)}$ の研究が挙げられる. CARRARA, HASENおよ びVAN WESTENの研究では, GISやリモートセンシン グを用い, 対象区域での斜面安定に関係する因子(地質, 傾斜角度, 谷密度, 断層, 植生, 地形分類等)の空間分布 図を作成し, 各因子の重要度に応じて点数を与え, 各因子 図を重㸚合わせすることによって総合的な評価指標分布図 を作成して, 斜面安定性のゾーニングを行った. 大林は, リモートセンシング技術を用い, 地形や表層地質, 土壊之 いった各種地理情報と衛星マルチスペクトルデータを融合 した斜面安定性評価モデルを提案し, 地形のフラクタル次 元を考慮する崩壊危険性評価を行った。しかしながら，こ 
れらの評価方法では, 斜面安定の力学的な解析が含まれず, 斜面安定の影響要因を統計学拉よびフラクタル, 遺伝的ア ルゴリズム等の視点から捉え, 斜面の安定性と結びつける 評価であるため, 結果の精度や信頼度には課題が残されて いる.

他方, 確定モデルでは, 斜面安定の力学的なモデルを用 い, 安定評価および八ザードマップの作成を行う. 確定モデ ルによる方法は，力学的なメカニズムを考慮した合理的な 方法であるが, 広域での評価には, 力学解析に必要な地盤の 標高, 傾斜角度, 傾斜方向, 弱層の分布等の多くの空間情 報が要求されるため, 研究は限られている. 代表的な研究 として, DIETRICH ${ }^{11)}$, MONTGOMERY $^{12)}$, TERLIEN ${ }^{13)}$, $\mathrm{PACK}^{14)}$ ，JIBSON ${ }^{15}$ 打よび $\mathrm{KHAZAI}^{16)}$ の研究が挙げられ る.これらの研究は, 一次元の無限斜面を想定し, 地震や 地下水の浸透等を考慮して, 斜面を構成する各地点の要素 （セル）のすべり安定率を求めることで斜面破壊八ザードマッ プを作成する．これらの研究では，一次元モデルであり， すべりの生じる地層厚さの推定には斜面の角度に比例する という経験計算式を用い, すべりの位置, 形状は考慮して いないため，地すべり発生の三次元現象を反映することが できない。

三次元斜面安定力学モデルを広域的に適用することによ る不安定斜面の抽出が望ましいが，これまでこのような研 究はほとんぞされていない，その原因は，広域解析に必要 な膨大な地形の幾何学情報やすべり面の形状, 空間位置等 が未知であったり，あし入手できたとしても膨大なデー夕 の取り扱いに問面があった。斜面の三次元安定解析では数 值解析や理論解析 (極限平衡法)がよく用いられている。特 に三次元斜面安定理論解析モデルとしては, HOVLAND ${ }^{177}$,

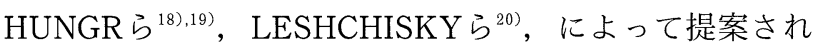
ているが, それを広域に適用して,多くのケーススタディに よる危険斜面の抽出は，極めて煩雑なメッシュ分割や幾何 デー夕の整理等が必要で，現実的に不可能である。さらに， 斜面崩壊の初期時点でのすべり面 (Critical slip surface) の三次元形状寸法打よび空間位置の抽出・判断は事実上未 開発である. 数值解析による三次元斜面安定解析にも同様 な問題がある。

近年，地理情報システム(GIS) はさまざまな分野に急速 に応用が進められている，GISは優れた空間情報の管理お よび解析能力を有しており，地盤災害の予測や対策への応 用にあ期待されている，GISを用いることによって斜面安 定解析に関わるさまざまな空間情報(地質, 地形, 土壤, 植生, 地下水位, 弱層分布等)の定量的把握が可能となり, これらのデジタル情報を高度に利用するプログラムを開発 し，従来の斜面安定解析方法をその中に取り入れることに よって，精度と信頼度のより高い広域の斜面安定評価予測 は可能と考えられる ${ }^{21,222}$ ．筆者らは，この方面の研究をい
くつか行ってきた $\left.{ }^{23)} 26\right)$ が，広域における危険斜面の自動 抽出扔よび系統的な研究等についてまだ問題が残っている.

本研究では，三次元解析に必要な膨大な情報をGISで処 理し, 地形や斜面のデジタルデー夕をもとに, 広域の各単 位斜面地形を抽出するとともに，三次元斜面安定理論解析 モデルによる安定解析を行う方法を開発する。次に，モン テカルロ法により数多くの試行計算を行い，広域に扔ける すべり危険性のあるすべり体の形状，位置を三次元的に抽 出する方法を提案する。また，その解析コードを開発し， その適用および方法の有効性について考察する.

\section{2. 研究全体の流れ}

本研究で提案する広域での三次元すべり危険斜面の抽出 方法は，数值地形情報と従来の三次元斜面安定解析理論 之 のカップリングであり，以下の 4 つのステップから構成さ れる。

(1)GIS空間データの準備

斜面安定に関わる地質, 地盤標高, 傾斜角度, 傾斜方向, 地下水位, 弱層等の空間分布をGISのデータとして整備し, それぞれの空間分布をデジタルデータとして定量的に把握 する。

(2)広域での各単位斜面(Slope Unit)の抽出

広域での斜面安定を評価する際，数值地形解析から平坦 な部分と斜面を区別し，地域での各単位斜面，すなわち， 傾斜方向がほぼ一致する各斜面を抽出する。本研究では, GISの地形解析による各単位斜面の自動抽出方法を提案し, その抽出結果を検討する.

(3)極限すべり面 (Critical slip surface)の模擬

抽出した各単位斜面に対して最すすべりやすいすべり面 (極限すべり面)の位置および三次元形状の抽出方法を提案 する，基本的には推定すべり体の空間形状拈よび位置をう ンダムに変えることによって多くのケースを設定し，それ ぞれのケースのすべり安全率を計算し，安全率が最小とな るすべり体を抽出する．安全率の計算には三次元極限平衡 法を使用する。

(4)広域での三次元すべり危険斜面の特定

以上の単一な斜面における三次元すべり試行計算をすべ ての斜面に適用することにより，広域でのすべり危険斜面 の抽出を実現する.

このような空間試行捜索解析方法は断面 2 次元の場合円 弧すべり試行計算と共通する点がある．2 次元の場合は断 面の幾何情報が簡単であるが，三次元の場合は地形㧍よび すべり面の情報は極めて複雑で，一般に空間試行計算が困 難である．GISの導入により地形等のデジタル情報を高度 に利用する解析コードを開発し，三次元空間試行計算が可 能になる。 


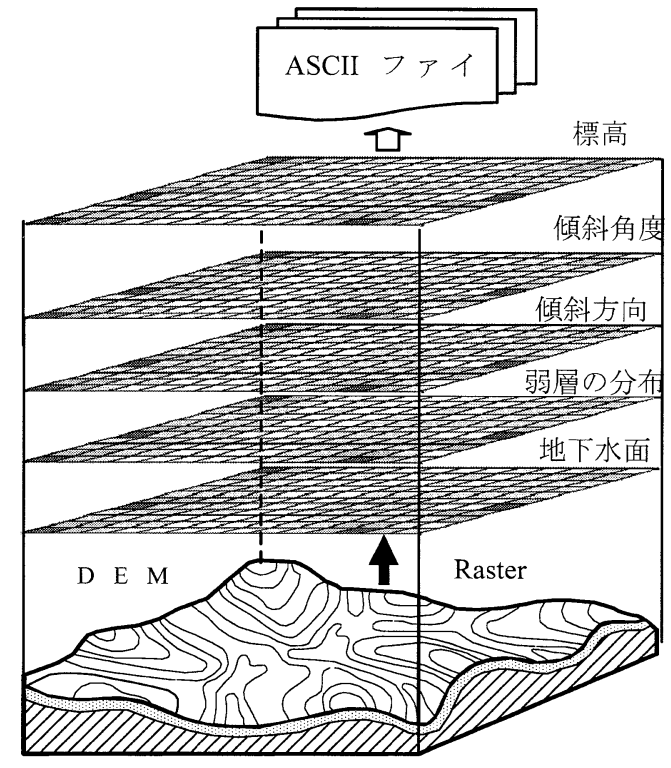

図-1＼cjkstart地形等のGIS空間データのデジタル化プロセス

\section{GIS空間データの準備}

GISはさまざまな空間デー夕(図形, 画像, 数值等の地 図上の情報)を統合して管理, 加工, 分析を行うッールで ある．実世界に存在するさまざまの空間情報(例えば，地 形, 道路, 河川, 地質, 植生等の分布)を点, 線および面 の 3 要素(ベクトルデータ)あるいはグリッド(メッシュ, ラスターデータ)によりその空間分布を表現するととむに， 属性デー夕をその図形(座標)に付属させることができる.

地形などのように広範囲で連続的に変化する現象の表現 にはラスターデータの形式が有利である。 ラスターデー夕 は, 正方形のセル(メッシュ)の集合体であり, 各セルの属性 情報として標高等の情報を与える.さらに, このようなセル のすべての情報(座標位置, 属性)をデジタルデータとして ASCIIの形式でGISから外部へ出力することが可能である.

斜面安定解析ためのGISデータの準備には, まず対象地 区の $1 / 2500$ の精度の地形図の等高線を線のデータ (Polyline data)としてGISに入力する. GISの空間内挿機 能を使い, 連続的に分布する標高のラスターデー夕を得る. 標高のラスターデータをベースに, 各セルでの傾斜角度, 傾斜方向の分布を計算する. 最後に対象範囲での標高, 傾 斜角度，傾斜方向のラスターデータをASCII形式でGISか ら外部へ出力する. 弱層や地下水面の分布も同じプロセス でデジタル化する．このような処理を行うことで，斜面安 定にかかわる情報の空間分布を数值的に把握することがで きる(図-1).

\section{4. 広域での各単位斜面 (Slope unit)の抽出}

自然地形は斜面および平坦な部分から構成される。自然 地形から平坦地(例えば，水平に近い土地）を取り除き，斜 面安定の評価対象となる斜面を検出し，それぞれの斜面の

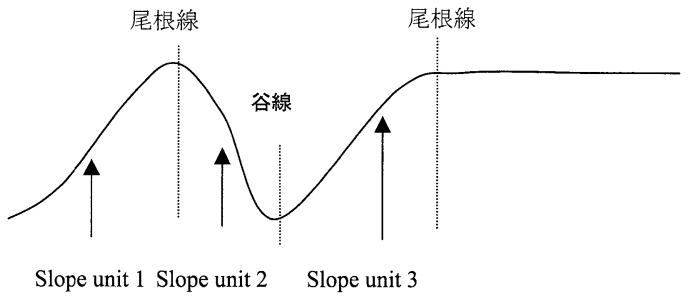

図-2 単位傾斜の概念

空間分布範囲を特定する。また，その範囲をGISのべクト ルデータ(例えば，多角形であるポリゴンシェップファイ ルデータ)として保存する.

図-2に示すように，一つの斜面(Slope unit)は基本的 に山の尾根線と谷線で囲まれた範囲である．斜面の抽出は 尾根線と谷線を特定できれば斜面の範囲を特定することが 可能となる.

数值地形 (DEM)による尾根線の抽出方法は古くから多 くの研究が行われてきている ${ }^{27), 28)}$. GISでは, 地形の標高 を比較することで，集水域(流域)を自動的に抽出し，集水 域の境界線(尾根線)をべクトルデータとして抽出するアル ゴリズムであり，下記の 3 つのステップ29)で構成される.

(1)数值地形の異常点の検出と処理 (Sink and fill)

数值地形の中に標高の内挿による誤差が生じる可能性が ある，例えば，地形のセルの中に標高が極めて低い孤立す るセルが存在する。このようなセルは集水域の抽出に影響 するため, 当該セルを見つけ, 周辺セルの標高の平均值を 与え直す。

(2)流れの方向の計算(Flow direction)

あるセルに対して周辺の 8 つのルの標高を比較し, 最 急勾配方向を計算する. 計算した方向值を流れの方向之し てセルに与える.

(3)集水域(流域)の計算(Watershed)

山地において規模の異なる集水域が存在するので, どの レベルの集水域を抽出するのかを予め設定することができ る. 集水域の最小面積(セルの数)を決めれば，その設定面 積を越える集水域を検出ことになる，集水域の最小面積は 単位斜面の規模にかかわるので, 研究対象地域の地質, 地 形，斜面崩壊の規模を考慮することで設定する.

この演算により集水域の境界(尾根線)をポリゴンデー夕 (多角の図形デー夕)として得られるが，谷線に関しては直 接に得られない. 本研究では，上記の数值地形に負の記号 をつけ(図-3)，同じプロセスを行い，新しい尾根線，つま り，谷線を特定する.

さらに，得られた尾根線および谷線のポリゴンデータの 2つレイヤーをユニオン処理(図-4)でマージすることによっ て，尾根線および谷線で囲まれたそれぞれの単位斜面を特 定することができる.

上記の単位斜面の抽出を実例として行った結果を図-5に 


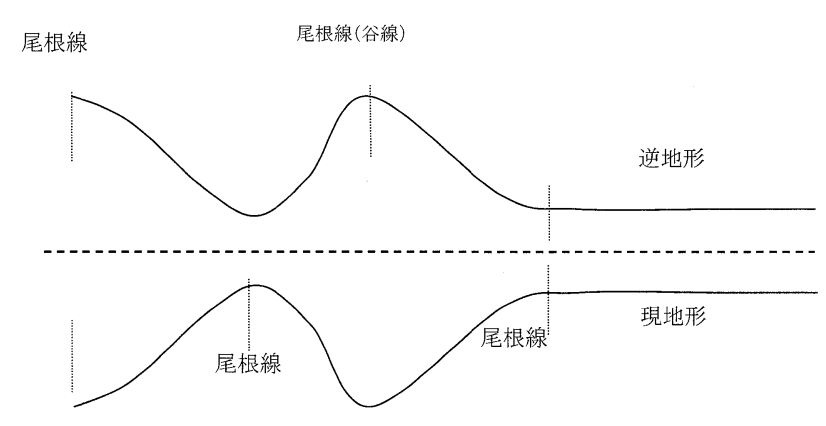

図-3 谷線特定の方法

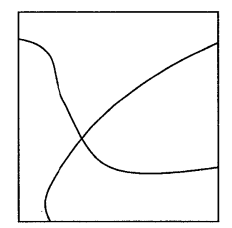

Input(尾根線)

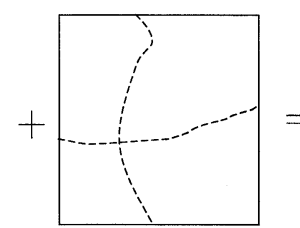

Overlay(谷線)

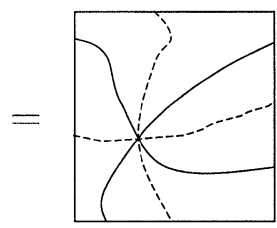

Output(単位斜面)
図-4ＧISのユニオン処理の概念図

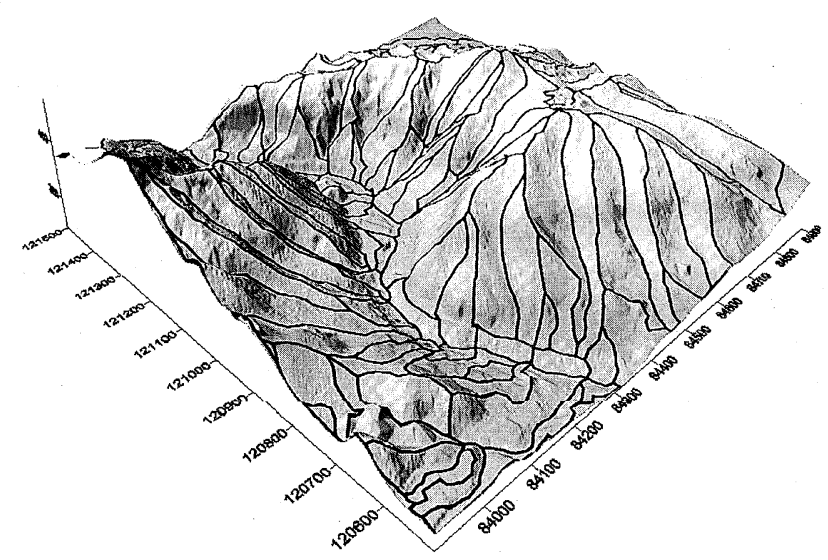

図-5 単位斜面の抽出結果 ( 3 次元図)

示す. 三次元地形の中に, 地形の谷線や尾根線を精確に抽 出しており, 谷線や尾根線で囲まれた範囲を単位斜面とし て特定し, 本研究で提案した方法により数值地形から斜面 の自動的かつ効率の良い抽出が可能であると考える。とく に，それぞれの単位斜面はポリゴンのデータ形式であるの で, GIS上でそのポリゴンによる地形標高, 傾斜角度, 傾 斜方向デー夕の統計妈理 (Focal statistics)を行い, 各単 位斜面内の地形の統計值(平均, 最大, 最小等)を得ること ができ，平坦な地形と斜面を判断することができる。また， それぞれの単位斜面はID番号を自動的に割り振られてお り, 番号順で各単位斜面のすべり試行計算ができる. 一方, 図の中に細い長い斜面が存在するが，これは長い谷である ことを示している。このGISの地形解析から各単位斜面の 範囲を数值的に把握し, 次の危険すべり体の試行計算ため の重要な基礎データとなる。

\section{5. 極限すべり面および危険すべり体の検出の提案}

\section{1 基本的な考え方}

広域における各単位斜面の分布を抽出した後，それぞれ

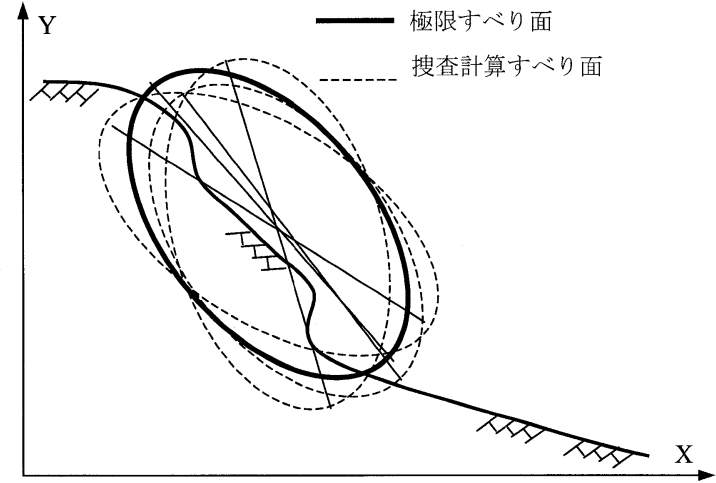

図-6 楕円体と地盤との交差面による極限すべり面の模擬と危険 すべり体の検出

の斜面を対象として潜在的に最む危険な三次元すべり体を 検出することになる.

しかしながら，最もすべりやすい三次元すべり体の検出 には，下記 3 つ問題を解決しなければならない.

(1) 極限すべり面の可能な形状(すべりが発生する直前のす ベり面)

(2) すべり体の可能な空間位置

(3) すべり体の可能な規模

過去に断面 2 次元の場合は潜在危険すべり面の検出に関 しては, MALKAWI ${ }^{30)}$, JIN-ZHANG ${ }^{31)}, \mathrm{KIM}^{32)}, \mathrm{ZHU}^{33)}$ 等が提案したものがあるが, 三次元的なすべり面の検出に 関する研究はない，過去多くの斜面崩壊事例加ら斜面不安 定の初期状態では，すべり面の三次元形状は楕球体の上う な底面の形状が多(4),177,199. そこで, 本研究では, 上記の 3 つの問題の解決に対して下記の提案を行う, まず，単位斜 面に対して, 任意の楕球体を地盤と交差させ, その交差面 を三次元すべり面とする，さらに，その楕球体の形状と寸 法を変えることによって, さまざまな潜在的なすべり面を 作り出す。この系列的なすべり面で囲まれたそれぞれのす べり体に対して, 三次元安定計算を行い, 最むすべり安全 率の小さいすべり体を検出する. 図-6は本研究で提案する 楕球体によりすべり面の模擬および危険すべり体検出の概 念図である。このような解析プロセスをすべての単位斜面 に適用することによって，広範囲において最むすべりやす いすべり体の空間的な検出を実現する.

すべりの発生は地質構造(層理面や断層)等の影響が極め て重要である。これらの影響を考慮するため, 弱層の空間 分布をボーリング等調査により明らかにし, その弱層の空 間分布をGISに入力する. 楕球体の下部が弱層と交差する 場合はその弱層面を含んだ複合すべり面を作成する(図-7). 広範囲では, 地質ボーリング調查から得られた弱層の空間 分布のデータの精度は比較的に粗い場合むあるので, その データの精度と影響を十分考慮して使用することが重要で ある.

提案した方法を具体的に実現するには下記の課題が存在 する. 


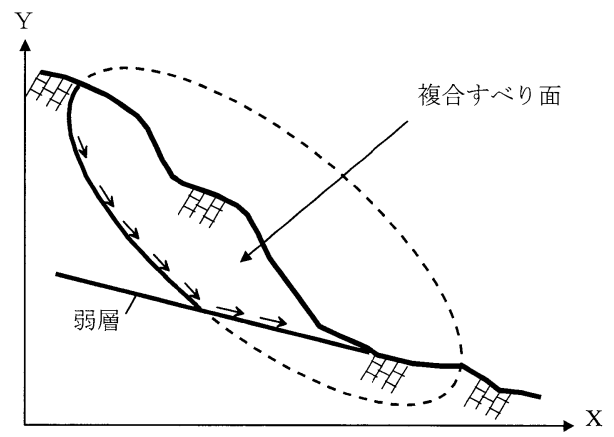

図-7＼cjkstart弱層面を利用する複合すべり面の作成

(1)地形等のデジタルデータに基づき楕球体の空間姿勢の決 定方法之計算式の導出

楕球体の傾き, 長短軸の位置等の姿勢に関して, 地形等 のデジタルデータ (座標, 標高, 傾斜角度, 傾斜方向等の 数値)をもとに決定する方法の検討が必要である.

(2)すべり体の三次元斜面安定性評価

棈球体の空間姿勢を決定した後, 楕球体の下部の地盤す べり体に対して, 速やかにすべり体の幾何学情報(地盤標 高, すべり面情報等)を取得し，すべり安全率の計算を行う (3)ランダムなケースの発生方法(異なる形状および寸法の 楕球体の発生)

ある斜面における最も危険なすべり体を検出するために， ランダムな形状および寸法の楕球体を斜面地盤と交差させ, 潜在的なすべり面を模擬するために，さまざまな形状な楕 球体を自動的に発生させ, 多くのケースから最小安全率の すべり体を抽出する方法を検討する。

本研究では, GIS空間デー夕(標高, 傾斜, 傾斜方向, 弱層)を利用し，楕球体の空間姿勢の決定およびランダム なケースの発生等の問題を解決するとともに，すべり安全 率の計算と危険すべり体の検出を行う.

\section{2 すべり体の空間姿勢の調整}

楕球体と地盤との交差面によりすべり面の形状を模擬す るには，楕球体の空間姿勢の決定と調整は極めて重要であ る. 本研究では, 下記のステップで楕球体の空間姿勢を決 定・調整する.

(1)楕球体の中心位置 $\left(X_{0}, Y_{0}, Z_{0}\right)$

抽出した単位斜面の平面範囲内において, $X_{0}, Y_{0}$ 座標 の乱数を発生し，楕円の中心を決定する，それから楕円の 範囲に囲まれた地形セルの標高值の平均值を計算し，それ を楕球体中心の $Z_{0}$ 値とする，座標変換を行うことによって 標準楕球体を $\left(X_{0}, Y_{0}, Z_{0}\right)$ に移動する.

(2)楕球体長軸の傾斜方向 (走向)

楕円の範囲に囲まれた地形セルの主傾斜方向を楕球体長 軸の傾斜方向とする．主傾斜方向は，傾斜方向値の頻度分 析から最も頻度の高い方向とする．楕球体の長軸がこの主 傾斜方向になるように座標の回転变換を行う.

(3)楕球体長軸の傾斜角度 (傾斜)

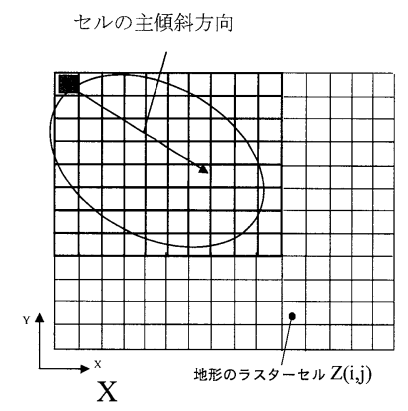

(a)

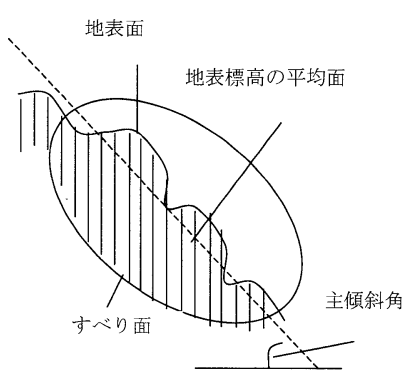

(b)
図-8 楕円体の長軸の方向の決め方 (a) と長軸の位置と傾斜角度 の決め方 $(\mathbf{b})$
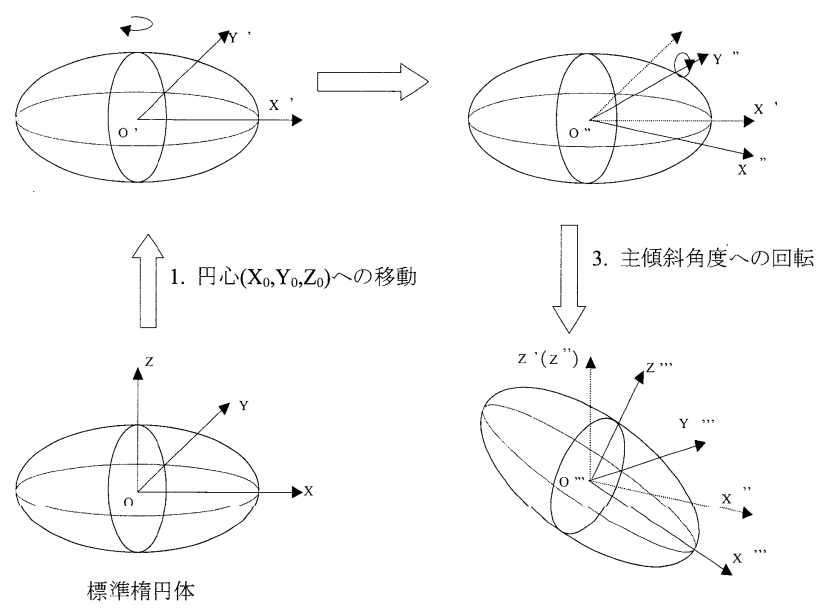

図-9 楕球体の姿勢の調整のための座標変換

楕円の範囲に囲まれた地形セルの主傾斜角度を棈球体長 軸の傾斜角度とする。この主傾斜角度も, 各セルの傾斜角 度值の頻度分析から決定する. 楕球体が主傾斜角度の傾き になるように座標の回転変換を行う。

図-8には前述の楕球体の空間姿勢を決める概念図を示す.

図-9には, 楕球体の移動, 傾斜方向之傾斜角度への回転 変換の概念を示す. このように座標変換を行うことによっ て棈球体の空間姿勢が決められる.

座標变換を行う際に, 地形の全体の座標系(例えば, UTM座標系, 平面直角座標系) 之楕球体自身の局所座標を 考慮する必要がある. 図-9に示される座標变換の基礎式は 下記のとおりである。

1) 楕球体中心 $\left(X_{0}, Y_{0}, Z_{0}\right)$ への移動

$$
\left\{\begin{array}{l}
x \\
y^{\prime} \\
z
\end{array}\right\}=\left[\begin{array}{lll}
1 & 0 & 0 \\
0 & 1 & 0 \\
0 & 0 & 1
\end{array}\right] \cdot\left\{\begin{array}{l}
x-x_{0} \\
y-y_{0} \\
z-z_{0}
\end{array}\right\}=B_{1} \cdot\left\{\begin{array}{l}
x-x_{0} \\
y-y_{0} \\
z-z_{0}
\end{array}\right\}
$$

2）主傾斜方向 $\alpha$ への回転

$$
\left\{\begin{array}{l}
x^{\prime \prime} \\
y^{\prime \prime} \\
z^{\prime \prime}
\end{array}\right\}=\left[\begin{array}{ccc}
\cos \alpha & -\sin \alpha & 0 \\
\sin \alpha & \cos \alpha & 0 \\
0 & 0 & 1
\end{array}\right] \cdot\left\{\begin{array}{l}
x^{\prime} \\
y^{\prime} \\
z^{\prime}
\end{array}\right\}=B_{2} \cdot\left\{\begin{array}{l}
x \\
y^{\prime} \\
z^{\prime}
\end{array}\right\}
$$

3)主傾斜角度 $\beta$ への回転

$$
\left\{\begin{array}{l}
x^{\prime \prime \prime} \\
y^{\prime \prime \prime} \\
z^{\prime \prime \prime}
\end{array}\right\}=\left[\begin{array}{ccc}
\cos \beta & -\sin \beta & 0 \\
0 & 1 & 0 \\
\sin \beta & \cos \beta & 0
\end{array}\right] \cdot\left\{\begin{array}{l}
x^{\prime \prime} \\
y^{\prime \prime} \\
z^{\prime \prime}
\end{array}\right\}=B_{3} \cdot\left\{\begin{array}{l}
x^{\prime \prime} \\
y^{\prime \prime} \\
z^{\prime \prime}
\end{array}\right\}
$$


この 3 つのステップをまとめると，下記の式になる.

$$
\begin{aligned}
\left\{\begin{array}{l}
x^{\prime \prime} \\
y^{\prime \prime \prime} \\
z^{\prime \prime \prime}
\end{array}\right\} & =B_{3} \cdot B_{2} \cdot B_{1}\left(\left\{\begin{array}{l}
x \\
y \\
z
\end{array}\right\}+\left\{\begin{array}{l}
-x_{0} \\
-y_{0} \\
-z_{0}
\end{array}\right\}\right) \\
& =\left[\begin{array}{ccc}
c_{1} c_{2}-s_{1} c_{2} & -s_{2} \\
s_{1} & c_{1} & 0 \\
c_{1} s_{2} & -s_{1} s_{2} & c_{2}
\end{array}\right] \cdot\left\{\begin{array}{l}
x-x_{0} \\
y-y_{0} \\
z-z_{0}
\end{array}\right\}
\end{aligned}
$$

または

$$
\left\{\begin{array}{l}
x \\
y \\
z
\end{array}\right\}=\left[\begin{array}{ccc}
c_{1} c_{2} & s_{1} & c_{1} s_{2} \\
-s_{1} c_{2} & c_{1} & -s_{1} s_{2} \\
-s_{2} & 0 & c_{2}
\end{array}\right]\left\{\begin{array}{l}
x^{\prime \prime} \\
y^{\prime \prime \prime} \\
z^{\prime \prime \prime}
\end{array}\right\}+\left\{\begin{array}{l}
x_{0} \\
y_{0} \\
z_{0}
\end{array}\right\}
$$

ここに, $s_{1}=\sin \alpha, c_{1}=\cos \alpha, s_{2}=\sin \beta, x, y, z$ は局 部座標, $x^{\prime \prime \prime}, y^{\prime \prime}, z^{\prime \prime \prime}$ は全体座標, $x_{0}, y_{0}, z_{0}$ は棈球体の中 心座標， $\alpha ， \beta$ はそれぞれ楕球体範囲内のセルの主傾斜方 向，主傾斜角度である。

\section{3 すべり体の三次元すべり安全率の計算}

次に，棈球体之地盤の交差面で囲まれた空間すべり体の 三次元安定計算を行う.

三次元斜面安定解析には，基本的に数值解析方法之理論 解析方法 (極限平衡法) の 2 手法がある. 数值解析方法には 三次元のメッシュの分割や応力の計算等が必要であり，か なり複雑な計算となる。本研究では多くのケーススタディ から危険斜面を抽出することを目的としており，極限平衡 法を用いることが現実的に望ましいと考える。楕球体と地 盤と交差させることにより特定したすべり体は規則的に分 布する柱状体群であるので，1977年にHOVLAND ${ }^{17)}$ が提 案した土柱の集合体を対象とした極限平衡法を使用する. この方法では, すべり範囲内のすべり体に対して, 柱状体 を分割し，すべり範囲内でのすべての柱状体のすべり力と 抵抗力をそれぞれ合計し，その比で三次元すべり安全率を 求めるあのである。計算式は下記のと抢りである.

$$
F_{3 d}=\frac{\sum_{x} \sum_{y}\left[\frac{c \Delta x \Delta y \sin \theta}{\cos \alpha_{x z} \cos \alpha_{y z}}+\gamma z \Delta x \Delta y \cos (D I P) \tan \phi\right]}{\sum_{x} \sum_{y} \gamma z \Delta x \Delta y \sin \alpha_{y z}}
$$

ここに， $F_{3 d}$ は三次元斜面すべり安全率， $\Delta x, \Delta y$ は土 柱のXとY方向の辺長, $\alpha_{\mathrm{xz} z} \alpha_{\mathrm{yz}}$ はすべり面とXZ面, YZ面 と形成する角度, DIPはすべり面の傾斜方向, $\theta$ は $\operatorname{arc}(\sin$ $\left.\alpha_{\mathrm{x} z} \cos \alpha_{\mathrm{y} z}\right), z$ は土柱の深さ, $\gamma$ は土柱の単位重量, $c$ 之 $\phi$ はそれぞれすべり面の粘着力, 内部摩擦角である.

式(6)に対して，分割方法よる安全率の計算では，土柱 の分割やその三次元幾何的デー夕の整理，入力は膨大な量 であり，非常に複雑な作業となる。また，すべり面を変化 させることによる試行計算は不可能である.

本研究では, 棈球体範囲内の土柱と相当する数值地形の セルの幾何的デー夕やすべり面の形状のデジタルデー夕を 利用することによって，上記のような複雑な入力データの 準備を解決する。
数值地形のセルの情報を利用した場合のHOVLAND三 次元斜面すべり安全率の計算式は以下の式(7)である(図10を参考).

$$
F_{3 D}=\frac{\sum_{I I}\left[\frac{c_{i i}}{\cos \theta_{i i}}+\left[\left(Z_{j i}-z_{j i}\right) \gamma^{\prime} \cos \left(\theta_{i j}\right) \cos \left(A s p_{i i}-A s p m\right)-u_{i j}\right] \tan \left(\phi_{j i}\right)\right.}{\sum_{J} \sum_{I}\left(Z_{i j}-z_{j i}\right) \gamma^{\prime} \sin \theta_{j i} \cos \left(A s p_{j i}-A s p m\right)}
$$

ここに， $\theta_{j i}$ とasp $p_{j i}$ は，セルの下部であるすべり面の傾 斜角度と傾斜方向, Aspmは主傾斜方向(すべり方向), $Z_{j i}$, $z_{j i}$ はセルの地表と下部すべり面の標高, $u_{j i}$ はすべり面に作 用する間隙水圧, c, $\phi$ は粘着力之内部摩擦角, $\gamma^{\prime}$ は土 の単位重量である。

\section{4 ランダムなケースの発生によるすべり体の捜查計} 算

単位斜面に対してすべり安全率が最小となるすべり体を 検出するための空間捜査計算を行う。その際, 楕球体の中 心位置, 楕球体の長軸および長軸と短軸の比をモンテカル ロ法により一様乱数として任意に設定する.

斜面すべり破壊の発生可能範囲は，その単位斜面内部だ けではなく, 斜面を越えた範囲の地盤すすべり体の一部分 になる場合がある。そこで，楕球体の中心位置を斜面内に ランダムに位置させるが, 棈球体が斜面範囲以外の地盤と 父差する場合はその地形む考慮する(図-11).

一様乱数之は, どの数が出る確率も等しいという確率分 布に従う乱数であり, その発生方法としては, 代表的な算

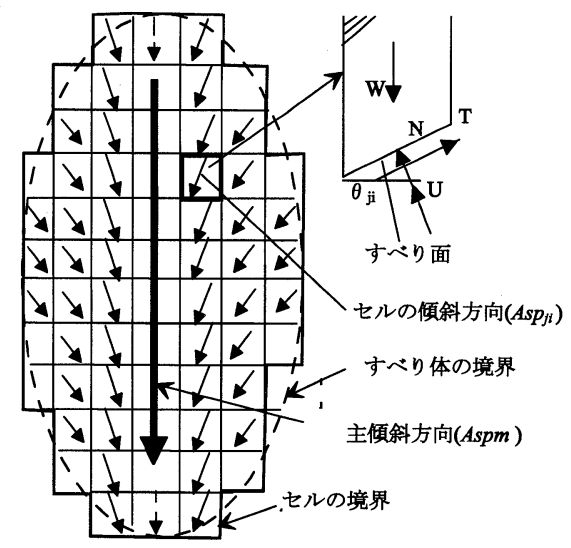

図-10 セルの情報を利用した三次元斜面安定計算

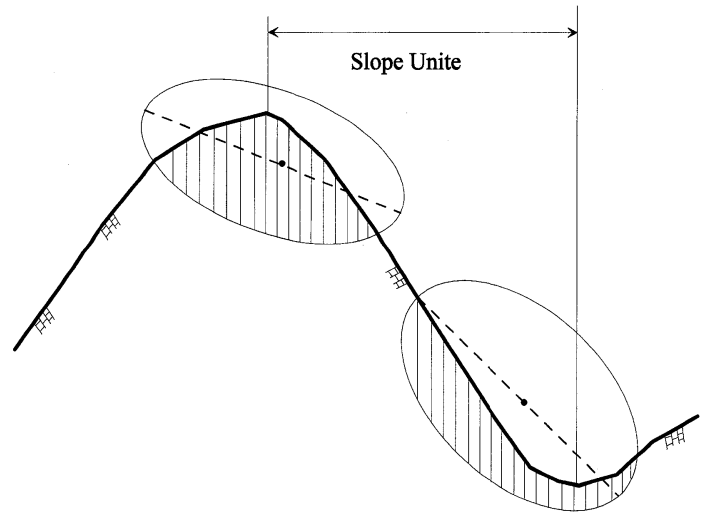

図-11＼cjkstart単位斜面以外の地盤と交差する場合のすべり体 
術方法である乗積合同法 (multiplicative congruential method)がある ${ }^{34)}$. 計算式は, 式(8)で表される.

$$
X_{n}=\lambda X_{n-1}(\bmod P)
$$

この式の右辺は， $\lambda X_{n \cdot 1}$ の值を $P$ で除算した余りを意味 する、 $\lambda$ とPは正の整数である。初期值 $X_{0}$ を与えれば, 式 (8) に従って乱数列 $\left(X_{1}, X_{2}, \cdots, X_{n}\right)$ が得られる. $X_{n}$ のと りうる值は $1 \leq X<(P-1)$ を満たすので, $P$ で割ることで 0 から 1 に分布する一様乱数列が得られる. この方法を楕球 体の空間姿勢の調整プログラムに取り入れることによって, 多くのケースを考慮することが可能である. しかし，この ような一様乱数の発生により生成した捜査計算ケースの数 は，理論上では無限である，実用上では，対象区域の地す ベり特徵, 地質, 崩壊のパターンを分析し, 可能なすべり 体の規模の变化範囲を確定し，より効率的な解析を実現す る。また，計算ケースの数は，プログラム上で設定できる ようにし，テスト計算により(例えば，200回，500回， 1000 回の捜査計算), 抽出したすべり体の位置と規模の变 化を調べ，最終的に決定することが望ましい.

\section{6. 解析コードの開発}

以上のすべてのプロセスを実行するために，Visual Basic およびGISのMapobjectのコンポーネントを用い, 「GIS-3DSLOPE」解析コードの開発を行った。コード開 発のフローチャートを図-12に示す.

このコードでは, デジタル地形や地層レイヤ(弱層)の情

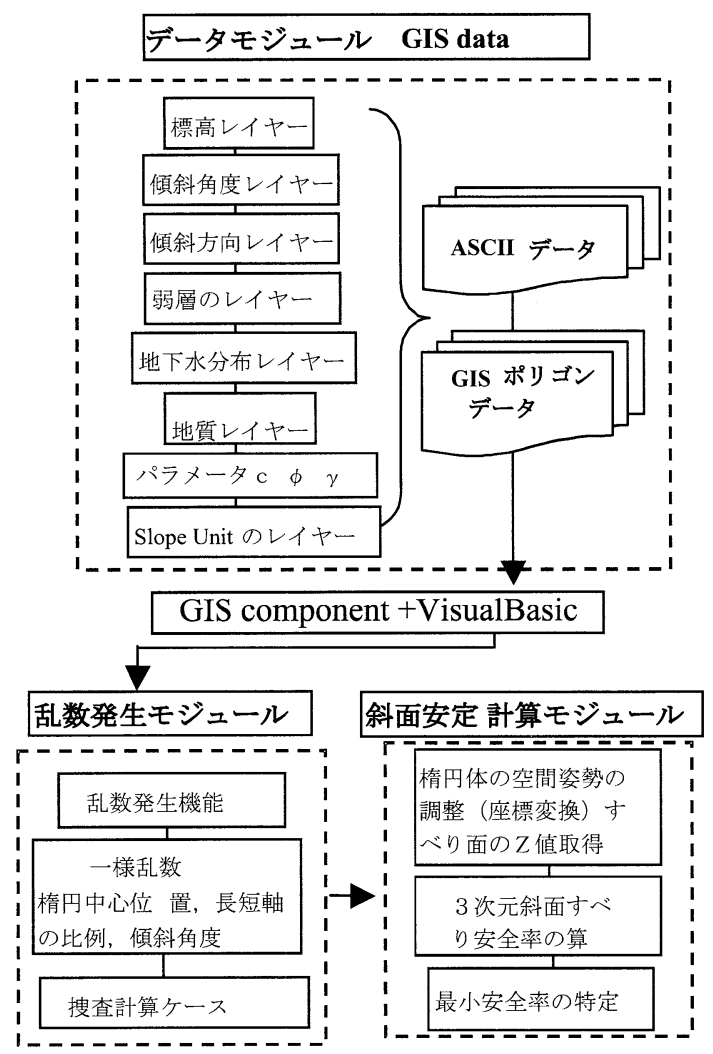

図-12 解析コード開発のフローチャート
報の読み込み, 一様乱数の発生, 棈球体の空間姿勢の決定, HOVLANDの三次元斜面安全率の計算および安全率が最 小となるすべり面の自動抽出等一連の解析プロセスが含ま れている.

\section{7. 適 用 例}

\section{1 検証計算}

本研究で提案した方法の信頼性を検証するために, 過去 多くの研究者 $\left(\mathrm{BALIGH}^{35)} \mathrm{GENS}^{36)}, \mathrm{LAM}^{37)}, \mathrm{HUNGR}^{18)}\right.$ ) に用いられる均質斜面での完全な球状すべり体(図-13)を

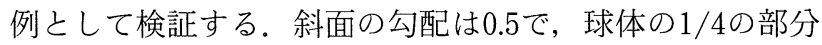
は地盤と交差する。球体の半径 $R=7.8 \mathrm{~m}$, 土の単位比重 $\gamma=1 \mathrm{t} / \mathrm{m}^{3}$, 内部摩擦角 $\phi=0$, 粘性力 $(c)$ の值は $c / \gamma R=0.1$ から得られる。過去の研究者(BALIGH, GENS, HUNGR およびLAM)がいくつかの仮定を前提条件とした理論解析 を行い，得られた三次元すべり安全率を表-1に示す．本研 究の提案方法によるすべり安全率は, セルサイズが $0.5 \mathrm{~m}$, $0.6 \mathrm{~m}$ であ場合, それぞれ1.396, 1.398 となている。こ れらの計算結果の比較を見ると，本研究で提案した方法は 各研究者の計算結果とほぼ合致していること $(F=1.4)$ がわ かった。

\section{2 地すべり地区への適用}

例として地すべり地区への適用を行う. 対象区域には, 約 5〜10 の緩斜面に旧地すべり堆積物が堆積しており, その厚さは10〜 20m 程度である.この区域で発生する地す べりは北松型地すべりと称されている。図-14にその模式 図を示す ${ }^{38), 39)}$. 北松型地すべりは，キャップロックである 玄武岩が継続的に移動し, その端部にある滑落崖が崩落す

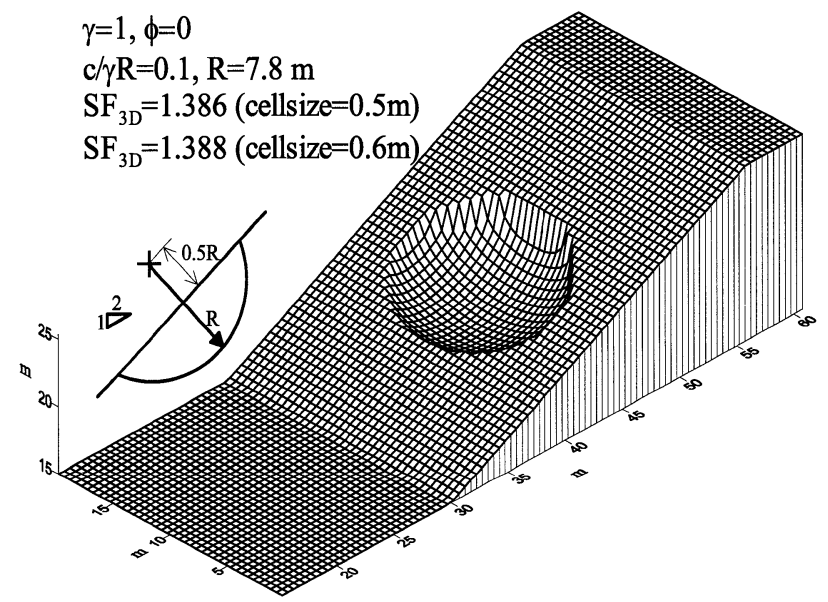

図-13 均質斜面での球状すべり体のすべり安全率計算

表-1 地盤の力学定数

\begin{tabular}{|c|c|c|}
\hline 研究者 & 計算の年代 & 3次元安全率 \\
\hline Baligh & 1975 & 1.402 \\
\hline Gens & 1988 & 1.41 \\
\hline Hungr & 1987 & 1.422 \\
\hline Lam & 1993 & $1.386-1.472$ \\
\hline 本研究 & 2003 & $1.396-1.398$ \\
\hline
\end{tabular}




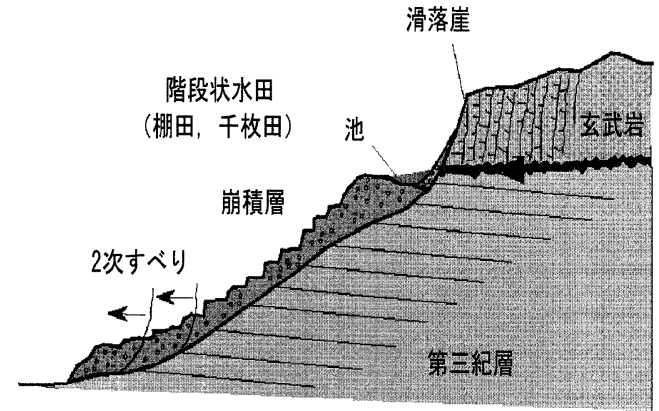

図-14＼cjkstart北松型地すべりの模式図

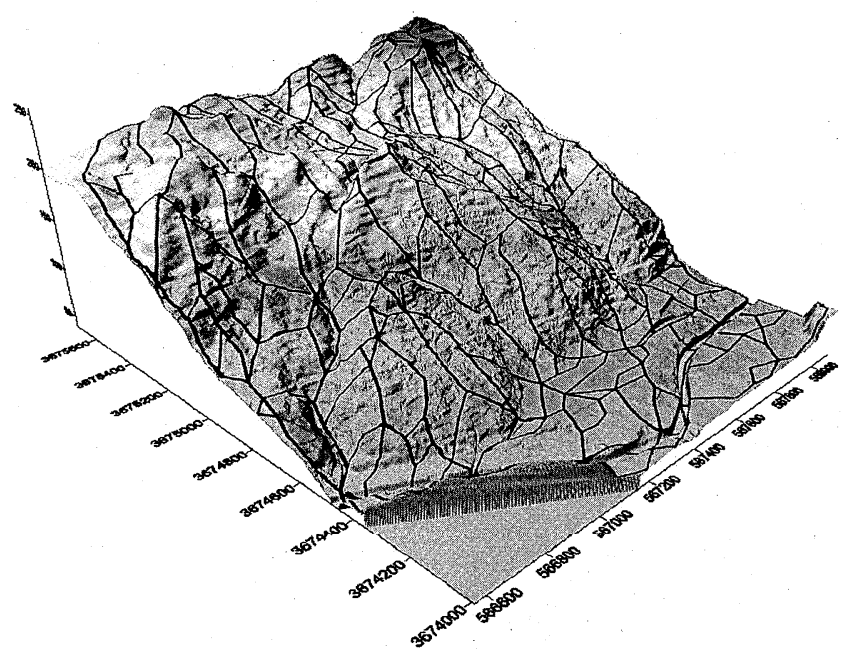

図-15 単位斜面の抽出結果

る北松 1 次すべりと, 崩落した崩積土砂が第三紀層の上に 堆積し, この崩積土砂の末端近くで2次的に発生する北松 型2次すべり(斜面破壊)に区分される。この崩積土砂の緩 傾斜地は, 階段状の水田として利用されていたが, 近年住 宅地になっており，2次すべりによる被害が急増している。

筆者らの先の研究 ${ }^{24}$ で当該区域の地質, 地形, 傾斜角度, 傾斜方向, 堆積物厚さの空間デー夕を構築した。本研究で は, まず数值地形から単位斜面(Slope unit)の抽出を行っ た(図-15). 次に, 本研究で開発した危険斜面抽出の解析 コードを用い，すべての斜面を対象として三次元危険斜面 の抽出を行った。使用する土質力学パラメー夕を表-2に示 す.

解析結果として, 安全率が1以下の各楕円すべり体と地 表面との交差線, つまり危険すべり体の平面位置を特定し た，図-16には各単位斜面，建物㧍よび危険すべり体の平 面位置を示す。図-16を見ると，地表面の起伏によりその 交差線が複雑な形状となっている。 また，実際に1997年 7 月に斜面崩壊が発生した地点では，本計算であ危険すべり 体として検出されたことが分かった。 また，予測したすべ り形状と規模は, 実際の崩壊後の形状と比べ, ほぼ一致し ていることが確認できた。また安全率が 1 以下であるほか の箇所では，現在斜面崩壊はまだ発生していないが，潜在 的な危険箇所として対策優先度が高い箇所であると考えら れる. 本研究で提案する三次元危険斜面の抽出方法により
表-2 地盤の力学定数

\begin{tabular}{|c|c|}
\hline パラメータ & 値 \\
\hline $\mathrm{c}$ & $10 \mathrm{kPa}$ \\
\hline$\phi$ & $10($ degree $)$ \\
\hline$\gamma$ & $16.4\left(\mathrm{~N} / \mathrm{m}^{-3}\right)$ \\
\hline$\gamma_{\mathrm{w}}$ & $10\left(\mathrm{~N} / \mathrm{m}^{-3}\right)$ \\
\hline
\end{tabular}

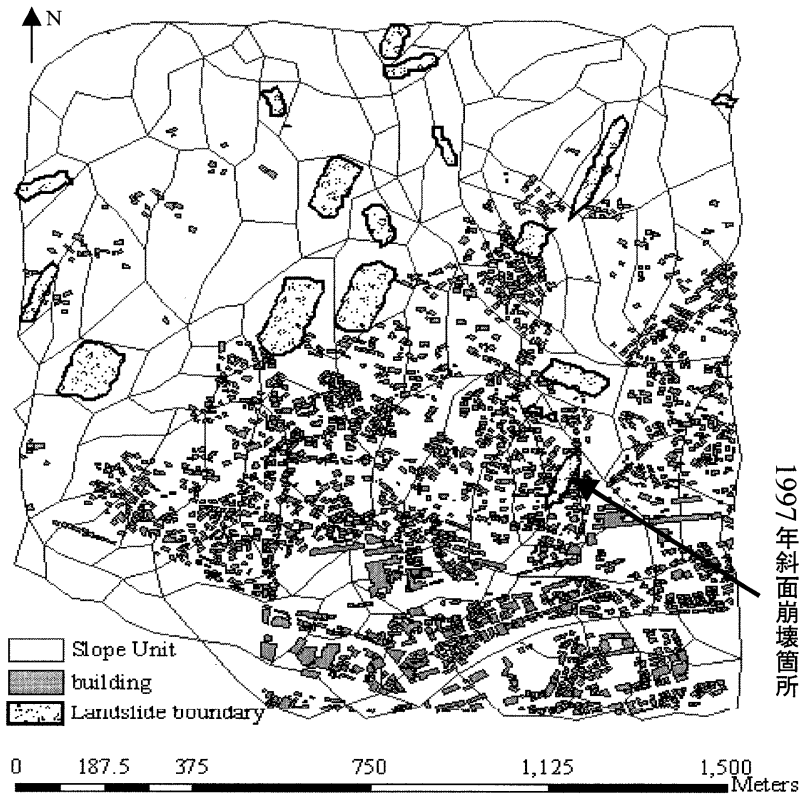

図-16 安全率が1以下の危険すべり体の平面分布範囲および建物 とのオーバーレイ図

広域的に潜在的な不安定箇所の形状，位置および周辺への 影響等を特定することができた。

今回は，約 $4 \mathrm{~km}^{2}$ の地すべり地域を対象としてシステム の応用を行い，検証を行った結果，この範囲にすでに発生 した崩壊のすべり箇所と一致したが，他のすべり予測箇所 の現場の比較確認が課題として残った。また，多くの現場 への適用を行うことで, 問題点の発見と改善を行い, シス テムの実用化への発展が必要である.

\section{8. ま と め}

本研究では，GISを用いた新しい広範囲での三次元危険 斜面抽出の方法の提案，検証抢よび応用を行った。主な結 論は下記のとおりである.

1） GISを用い斜面安定解析にかかわるさまざまな空間情 報(地質, 地形, 地下水位, 弱層分布等)を定量的に把握し, これらのデジタル情報を高度に利用することによって, 広 域的に斜面地形の抽出や三次元危険斜面の特定に新しい方 法を提案した。

2）本研究で提案したデジタル地形情報に基づきGISの解 析による斜面地形の抽出方法は広域的に分布する各単位斜 面の分布範囲を正確に特定することができた．

3）棈球体と地盤との交差面により三次元すべり面を模擬 し, 棈球体の曲率や形状を変えることによって, 多くのす べり面を作成し, 試行による安全率の計算結果から最もす 
ベり安全率の小さいすべり体の位置，形状执よび寸法の検 出ができた。検証解析の結果により, その正確性が確認で きた。

4）GISにより地形(標高, 傾斜角度, 傾斜方向)のデジ夕 ルデー夕を作成し，それを利用することで，従来の三次元 斜面安定の理論解析におけるすべり体の幾何的なデー夕の 作成と比べ，精度および作業効率を大幅に向上させること が明らかになった。

5）この方法は極めて広域加ら危険斜面を抽出する合理的 方法であると考えられる. 方法の実用化等についてまだ課 題を残しているが，この方面への展開は土砂災害の防止対 策に対しては極めて重要であると考える。

謝辞 本研究の内容は情報処理振興事業協会 (IPA) 加らの 研究助成を受けて実施した成果の一部である。ここに記し て感謝の意を表します。

\section{引 用 文 献}

1) CARRARA, A.(1983): Multivariate models for landslide hazard evaluation, Mathematical Geology, Vol.15, pp.403426.

2) CARrara,A., CARdinAli,M., DETTI,R., GUZZETTI,F., PASQUI,V. and REICHENBACH, P.(1991): GIS techniques and statistical models in evaluating landslide hazard, Earth Surface Process. and Landforms, Vol.16, pp.427-445.

3) CARRARA,A.(1993) : Potentials and pitfalls of GIS technology in assessing natural hazards. In : Proceed. Int. Workshop GIS in Assess. Nat. Hazards, Perugia, Sept. 1993, ed(s)REICHENBACH, P., GUZZETTI, F. and CARRARA, A., pp.128-137.

4) HANSEN, A.(1984) : Landslide hazard analysis, In Slope instability, ed(s). Brunsden D., and Prior D.B., pp.523-602. New York: Wiley.

5) HANSEN, A., and Franks C.A.M.(1991) : Characterization and mapping of earthquake triggered landslides for seismic zonation, Proceed. IV Int. Conf. Seismic Zonation, Stanford, California, August 26-29, 1991, pp.149-195.

6) HANSEN, A., FRANKS, C.A.M., KIRKP. A., and BRIMICOMBE, A.J.(1995) : The application of GIS to landslide hazard assessment in Hong Kong, In Geographical Information Systems in Assessing Natural Hazards, ed(s) Carrara A. and Guzzetti F., The Netherlands : Kluwer Pub. Dordrecht, pp. 155-163.

7) VAN WESTEN, C.J.(1993) : Application of Geographic Information System to landslide hazard zonation, The Netherlands, ITC Publisher.

8) VAN WESTEN,C.J.(2000) : The modeling of landslide hazards using GIS, Surveys in Geophysics, Vol.21 No.2, pp.241255.

9）大林成行 - 小島尚人 - Chang-Jo F.CHUNG (1999）：斜面安定 性評価モデルの精度比較とその実用化への提案,「土木学会論 文集」, No.630/VI-44, pp.77-89.
10）大林成行・小島尚人・藤井克史 (1996)：衛星マルチスペクト ルデータを適用した地すべり危険箇所の評価精度の向上, 土木 学会論文集, No.534/VI-30, pp.173-184.

11)DIETRICH, W.E., WILSON, C.J., MONTGOMERY, D.R. (1993) : Analysis of erosion thresholds, channel networks, and landscape morphology using a digital terrain model. Journal of Geology, Vol.101, pp.259-278.

12)MONTGOMERY, D.R. and DIETRICH, W.E.(1994) : A physically based model for the topographic control on shallow landsliding. Water Resources Research, Vol.30, No.4 pp.153-1171.

13)TERLIEN, M.T.J.(1996) : Spatial distribution of variables and parameters. In Modeling Spatial and Temporal Variations in Rainfall-Triggered Landslides, ed(s) M.T.J. Terlien, ITC Publisher, pp.99-114.

14)PACK,R.T., TARBOTON, D. G. and GOODWIN, C.N.(1998) : The SINMAP Approach to Terrain Stability Mapping, Proc. of 8th Congress of the Int. Association of Engineering Geology, Vancouver, British Columbia, Canada 21-25 September, 1998, pp.44-50.

15) JIBSON, R. W., HARP, E. L. and MICHAEL. J. A.(1999) : A modeling procedure to produce probabilistic seismic landslide hazard maps, Abstracts with Programs. Geological Society of America, 1999 annual meeting, Vol.31. No.7, pp.195-200.

16)KHAZAI,B. and SITAR,N.(2000) : Assessment of seismic slope stability using GIS modeling, Geographic Information Sciences, Vol.5, No.2, pp.121-128.

17)HOVLAND, H.J.(1977): Three-dimensional slope stability analysis method, Journal of the Geotechnical Engineering, Division Proceedings of the American Society of Civil Engineers, 103(GT9), pp.971-986.

18)HUNGR, O.(1987) : An extension of Bishop's simplified method of slope stability analysis to three dimensions, Geotechnique, Vol.37, No.1, pp.113-117.

19)HUNGR, O.(1994) : A general limit equilibrium model for three-dimensional slope stability analysis, discussion. Canadian Geotechnical Journal, Vol.31, pp.791-795.

20)LESHCHISKY, D. and HUANG, C.(1992) ; Generalized three dimensional slope stability analysis, Journal of Geotechnical Engineering, Vol.118, No.11, pp.1748-1763.

21)江崎哲郎・周国云 (1997)：連載講座GIS入門(4), 地盤環境問 題へのGIS応用, トンネルと地下, Vol.28, No.4, pp.63-68.

22)江崎哲郎 ・周国云 (1997)：連載講座GIS入門(最終回), 建設分 野へ利用の実態および将来展望, トンネルと地下, Vol.28, No.5, pp.65-70.

23) 周国云・江崎哲郎・謝謨文・三谷浩泰 (2002)：GIS とモンテカ ルロ法を用いた新しい三次元空間斜面安定評価方法の提案,土 之基礎, Vol.50, No.5, pp.23-25.

24)G. ZHOU,T. ESAKI, Y. MITANI, M. XIE and J.MORI (2003) : Spatial probabilistic modeling of slope failure by using GIS and Monte Cairo method, International Journal of Engineering Geology, Vol.68, issues 3-4, 2003, pp.373-386.

25) Mowen XIE, Tetsuro ESAKI, Guoyun ZHOU and Yasuhiro MITANI(2003) : Three-dimensional stability evaluation of landslides and a sliding process simulation using a new geographic information systems component, International Journal of Environmental Geology, Vol.43, No.5, pp.503-512. 
26)M. XIE, T. ESAKI, G.ZHOU and Y. MITANI(2003) : GISbased 3D critical slope stability analysis and landslide hazard assessment, ASCE, Journal of Geotechnical and Geoenvironmental Engineering, ASCE, No.12, pp.1109-1118.

27)近藤昭彦 (1996)：数值地形モデル（D E M）による流域情報抽 出,平成7年度文部省科学研究費補助金(総合 $\mathrm{A}$ ) 成果報告書「衛 星・航空機・地上同時観測デー夕を用いた多元的高分解能の 流域環境解析」, pp.83-90.

28) 中山大地 (1998)：DEMを用いた地形計測による山地の流域分 類の試み, 地理学評論, 第71巻, 第3号, pp.169-186.

29) Environment Research Institute(ESRI) (1998) : The spatial analyst function, ArccView Sapatial Analyst, USA : ESRI Press, pp.104-109.

30) AI Husein MALKAWI, W. F. HASSAN, and S. K. SARMA (2001) : An efficient search method for finding the critical circular slip surface using the Monte Carlo technique, $\mathrm{Ca}$ nadian Geotechnical Journal, Vol.38, pp.1081-1089.

31) JIN-Zhang Z., WILLIAMS D.J. and WEN-Lin X.J(1996) : Search for critical slip surfaces based on finite element method, International Journal of Rock Mechanics and Mining Sciences and Geomechanics, Vol.33, No.3, pp.137A137A (1).

32)KIM J.Y. and LEE S.R.(1997) : An improved search strategy for the critical slip surface using finite element stress fields, Computers and Geotechnics, Vol.21, No.4, pp.295-313.

33)Da-Yong ZHU(2001): A method for locating critical slip surfaces in slope stability analysis, Canadian Geotechnical Journal, Vol.38, pp.328-337.

34)津田孝夫(1997)：モンテカルロ法とシミュレーション,電子計 算機の確率論的応用, 培風館, pp.120-190.

35)BALIGH, M.M. and AZZOUZ, A.S.(1975) : End effects on the stability of cohesive slopes, ASCE Journal of the Geotechnical Engineering Division, Vol.101,(GT11), pp.11051117

36)GENS, A, HUTCHISON, J.N. and CAVOUNIDIS, S.(1988) : Three dimensional analysis of slices in cohesive soils, Geotechnique, Vol.38, pp.1-23.

37)LAM, L. and FREDLAND, D.G.(1993) : A general limit equilibrium model for three-dimensional slope stability analysis, Canadian Geotechnical Journal, Vol.30, pp.905919.

38)長崎見県北振興局(1997)：平成9年度原分地区地すべり調査報 告書.

39) 太出文吾(1969)：長峆県北松地区における地すべり発生機構 の特性, 地すべり, Vol.6, No.1, pp.23-33.

（2004年 3 月 8 日受付，2004年11月12日受理）

\title{
GIS-Based Three-Dimensional Landslide Evaluation System Development and Its Application
}

\author{
Guoyun ZHOU, Tetsuro ESAKI , Mowen XIE and Yasuhito SASAKI
}

\begin{abstract}
A GIS-based thee dimensional landslide prediction systems is proposed. Firstly, all single slopes(Slope unit) are identified by proposed GIS terrain analysis. Secondly, 3D slip surface is modeled by using an interface between ground and an ellipse. The spatial posture of this ellipse is determined based on the digital data of terrain elevation, aspect and slope angle. A modified HOVLAND's three dimensional slope stability safety factor equation is used. By using Monte Carlo simulation technique, the spatial posture of the ellipse and the ellipse curvature can be randomly changed, and by calculating the safety factor for all the cases the critical slide surface, which gives minimum safety factor for slope failure, can be found and corresponding critical spatial slide volume can be determined for every slope in entire area.
\end{abstract}

Key words : landslide, 3D slope failure, GIS, Monte Carlo simulation 